\title{
ANALISIS PENERAPAN SISTEM PENGENDALIAN INTERN PENJUALAN KREDIT PADA PT. NUSANTARA SURYA SAKTI BENGKULU
}

\author{
${ }^{1)}$ Indah Fitria, SP., M.Si, ${ }^{2)}$ Rika Dwi Yulihartika, SP., M.Sc \\ Program Studi Agribisnis Fakultas Pertanian UNIVED \\ Email indahfitria@unived.ac.id
}

\begin{abstract}
ABSCTARCT
This internal control system is run to provide reasonable assurance about the achievement of objectives that is, reliability of financial reporting, compliance with applicable laws and regulations, effectiveness and efficiency of operations. Therefore it is necessary to evaluate the internal control system to the sale to maintain the survival of the company and the achievement of corporate objectives The purpose of this study Knowing to know how the implementation of internal control system of credit sales at PT. Nusantara Surya Sakti Bengkulu and whether the system of internal control system of credit sales at PT. Nusantara Surya Sakti Bengkulu has fulfilled the Internal Control System based on generally accepted accounting principles (PABU)

This study uses a type of comparative analysis research. This method is a presentation of data derived from the problems faced by the company, from the problems that are analyzed by using an approach based on existing theories then compare with what is realized in the object of research

The results of research network designation procedures that form the credit sales system at PT. Nusantara Surya Sakti Bengkulu is sales order procedure, delivery procedure, billing procedure, account receipt procedure, and sales distribution procedure. In the procedure that forms the credit sales system at PT. Nusantara Surya Sakti Bengkulu is running well.
\end{abstract}

Keywords: Implementation, internal control system, credit sales

\section{PENDAHULUAN}

\section{Latar Belakang}

Perkembangan perusahaan saat ini semakin pesat. Era saat ini mendorong banyak perusahaan untuk semakin memperluas usahanya dengan meraih pangsa pasar. Hal tersebut mendorong terjadinya persaingan ketat antar perusahaan. Perusahaan adalah suatu instansi yang terorganisir, berdiri dan berjalan yang tidak dapat terlepas dari hukum ekonomi dan prinsip dasar perusahaan pada umumnya. Perusahaan didirikan untuk mencari laba yang sebesar-besarnya dan untuk 
dipertahankan kelangsungan hidup usahanya.

Perusahaan banyak melakukan usaha untuk mencapai tujuannya itu. Perusahaan harus tetap berusaha mempertahankan kelangsungan usahanya di masa yang akan datang. Usaha yang dilakukan pasti memiliki kemampuan untuk menghasilkan profit dan keuntungan. Perusahaan yang didirikan ada dua macam, yaitu di bidang jasa dan manufaktur. Tentu saja kelangsungan usaha ini dapat terwujud jika barang atau jasa yang ditawarkan dapat diterima di pasaran, dan dapat menarik pangsa pasar. Oleh karena itu, penting untuk perusahaan mempelajari sistem penjualan, karena penjualan merupakan sumber penghasilan bagi perusahaan. Penjualan yang sukses adalah penjualan yang dapat menguasai pangsa pasar. Dengan peningkatan penjualan maka laba yang akan diperoleh perusahaan akan meningkat serta perusahaan akan dapat melanjutkan kelangsungan hidupnya.

Sistem pengendalian intern terhadap penjualan pada suatu perusahaan dapat dikatakan memadai apabila dalam pelaksanaanya terdapat suatu peningkatan dalam penerimaan kas oleh perusahaan itu sendiri. Sistem Pengendalian Intern terhadap penjualan pada suatu perusahaan belum bisa dikatakan memadai jika target dalam penjualan produk yang telah direncanakan tidak terpenuhi, sehingga pihak manajemen perlu meningkatkan pengendalian intern manajemennya. Dengan adanya pengendalian intern yang telah direncanakan sebelumnya akan memperkecil kemungkinan penyelewengan terhadap prosedur penjualan dan penerimaan kas akan dapat diketahui oleh pihak manajemen (Mulyadi, 2008:9).

Penjualan produk secara kredit umumnya ditujukan untuk menaikan volume penjualan. Akan tetapi, penjualan produk secara kredit ini sering kali menimbulkan masalah yang cukup kompleks yang memerlukan penanganan tersendiri untuk menyelesaikannya. Masalah yang sering kali dihadapi adalah

proses penagihan piutang, sehingga sering terjadi kasus piutang tak tertagih (bad debt) atau sering disebut dengan kredit macet. Masalah lainnya adalah bahwa piutang tak tertagih 
tersebut hampir selalu terjadi di setiap bulan, yang tentunya memperlambat penerimaan kas atas piutang perusahaan. Faktor penyebab bisa dari pihak konsumen, misalnya sengaja mengulur-ulur waktu waktu pembayaran yang sudah jatuh tempo, atau dari pihak perusahaan itu sendiri, misalnya keterlambatan dalam melengkapi dokumen-dokumen penagihan (Iriyadi, 2014:24).

Evaluasi mengenai sistem pengendalian intern penjualan ini akan memberikan informasi-informasi yang penting bagi perusahaan dalam menjalankan usahanya dengan baik, dan dapat meningkatkan usahanya. Tentu saja aktivitas penjualan akan menghasilkan produktivitas yang optimal jika diimbangi oleh sistem pengendalian intern penjualan yang baik (Mulyadi, 2008:7).

Sistem pengendalian intern ini dijalankan oleh dewan komisaris, manajemen dan dewan personil lain yang didesain untuk memberikan keyakinan memadai mengenai pencapaian tujuan yaitu, keandalan pelaporan keuangan, kepatuhan terhadap hukum dan peraturan yang berlaku, efektivitas dan efisiensi operasi. Oleh karena itu diperlukan evaluasi mengenai sistem pengendalian intern terhadap penjualan untuk tetap mempertahankan kelangsungan hidup perusahaan serta tercapainya tujuan perusahaan (Sukrisno, 2004:9).

Dengan melihat kondisi perusahaan secara langsung yang menangani tentang penjualan kredit motor dan mengingat minat para konsumen yang tinggi dalam menginginkan kendaraan roda dua tersebut, maka peneliti tertarik untuk membahas masalah ini, bagaimana pengendalian intern yang sudah dilakukan perusahaan ini dapat terus melakukan perbaikan dan peningkatan dari waktu ke waktu sehingga perusahaan dapat mengatasi faktor resiko yang akan timbul seiring dengan berkembangnya bisnis ini sehingga perusahaan dapat mencapai keuntungan yang maksimal. Melihat pentingnya pengendalian intern dalam sistem penjualan kredit dan piutang usaha tersebut seperti penjelasan diatas peneliti tertarik melakukan penelitian dengan judul “Analisis Penerapan Sistem Pengendalian Intern Penjualan Kredit Pada PT. 
Nusantara Surya Sakti Bengkulu“.

Sesuai dengan rumusan masalah, maka tujuan penelitian ini adalah 1 . Untuk mengetahui bagaimana penerapan sistem pengendalian intern penjualan kredit pada PT. Nusantara Surya Sakti Bengkulu. 2. Untuk mengetahui Bagaimana sistem akuntansi penjualan kredit pada PT. Nusantara Surya Sakti Bengkulu.

\section{METODE PENELITIAN}

Penelitian ini dilaksanakan bertempat pada pada PT. Nusantara Surya Sakti Bengkulu yang terletak di Jalan Mahakam Raya No. 23 Lingkar Barat, Kecamatan Cempaka Kota Bengkulu pada bulan Agustus 2020. Penelitian ini menggunakan jenis penelitian deskriptif kualitatif dengan pendekatan studi kasus. Menurut Sugiyono (2008;99) Data Kualitatif, yaitu data yang berupa penjelasan / pernyataan yang tidak berbentuk angka yang diperoleh dari PT. Nusantara Surya Sakti Bengkulu, misalnya seperti data tentang kebijakan akuntansi yang diterapkan oleh perusahaan serta struktur organisasi perusahaan. Data dan Jenis Data Data yang digunakan dalam penelitian ini adalah data sekunder, Menurut
Arikunto, (2010:99) data sekunder merupakan sumber data penelitian yang diperoleh oleh peneliti secara tidak langsung atau melalui media perantara. Data yang dikumpulkan yaitu mengenai prosedur akuntansi serta kebijakan perusahaan dan data penjualan perusahaan secara kredit, kemudian laporan-laporan yang telah dihasilkan oleh perusahaan seperti laporan keuangan perusahaan.

\section{Teknik Pengumpulan Data}

Dimensi waktu penelitian adalah cross sectional yang berarti penelitian hanya dilakukan sekali pada waktu tertentu. Metode yang digunakan adalah metode wawancara, observasi, dan survei dokumen.

Observasi, dilakukan untuk mengumpulkan data secara detail. Observasi dilakukan dengan mengamati secara langsung proses dari awal penawaran hingga penjualan motor secara kredit pada nasabah.

Wawancara, ini dilakukan kepada staft PT. Nusantara Surya Sakti Bengkulu, dan kepada kepala Marketing Pemasaran dan Kepala Gudang. Untuk mendapatkan informasi tentang sistem 
pengendalian intern yang berlaku pada perusahaan.

Dokumen, ini dilakukan dengan cara melihat dokumen-dokumen yang terkait dengan sistem penjualan, dan membaca buku yang berhubungan dengan sistem penjualan. Kemudian dokumentasi juga berupa Sturuktur organisasi PT. NSS Bengkulu

\section{Teknik Analisis data}

Metode analisis data yang digunakan oleh peneliti adalah analisis komparatif. Metode ini merupakan penyajian data yang berasal dari masalah yang dihadapi perusahaan, dari masalahmasalah itu dilakukan analisis dengan menggunakan pendekatan yang didasarkan pada teori-teori yang ada kemudian membandingkan dengan apa yang direalisasikan pada objek penelitian. Metode analisis data pada penelitian ini dengan menggunakan unsur sistem pengendalian intern, yaitu: 1.Struktur organisasi.

2.Otorisasi dan prosedur pencatatan.

3. Praktik yang sehat.

4.Karyawan yang mutunya sesuai dengan tanggung jawabnya. Pengujian dilakukan pada kelengkapan dokumendokumen seperti formulir penjualan dan bukti-bukti transaksi lainnya, otorisasi yang terdapat dalam dokumen dan nomor urut yang tercetak pada dokumen tersebut. Aktivitas pengendalian yang diteliti terhadap faktur penjualan adalah : Penggunaan formulir faktur penjualan yang bernomor urut, Adanya pertanggungjawaban penggunaan formulir faktur penjualan yang bernomor urut tercetak tersebut, Tanda tangan otorisasi atas faktur penjualan dari yang berwenang.

Kesesuaian informasi yang dicantumkan dalam faktur penjualan dengan informasi yang tercantum dalam dokumen pendukungnya,

Kelengkapan dokumen pendukung faktur penjualan

Tanda tangan otorisasi atas dokumen pendukung dari yang berwenang.

Kesesuaian harga jual, syarat penjualan, dan potongan yang tercantum dalam faktur penjualan dengan peraturan yang berlaku mengenai hal tersebut.

Periksa bukti digunakannya formulir bernomor urut tercetak dan pertanggung jawaban atas formulir tersebut. 


\section{HASIL DAN PEMBAHASAN}

\section{Sejarah singkat PT. Nusantara surya sakti bengkulu}

PT. Nusantara surya sakti bengkulu berdiri pada tahun 2004 di jalan mahakam raya no. 23 lingkar barat, kecamatan cempaka kota bengkulu. Pertama kali berdiri, PT. Nusantara surya sakti bengkulu hanya memiliki kantor kecil yaitu sebuah bangunan rumah, dengan jumlah kayawan kurang lebih 20 orang. Pertengahan tahun 2005 PT. Nusantara surya sakti bengkulu mengalami musibah kebakaran yang mengakibatkan seluruh bangunan kantor habis terbakar. Setelah kejadian tersebut PT. Nusantara surya sakti Bengkulu pindah ke jl. Kapuas raya tidak jauh dari lokasi kantor yang lama. Pada tahun 2008 bangunan kantor yang lama selesai diperbaiki dan menjadi salah satu dealer honda terbesar di bengkulu. PT.Nusantara surya sakti Bengkulu mengalami kemajuan yang sangat pesat dalam kurun waktu 2 tahun, Nusantara surya sakti Bengkulu sudah menjadi salah satu dealer resmi sepeda motor honda dengan penjualan terbanyak untuk daerah bengkulu, mengalahkan penjualan dealer-dealer resmi sepeda motor honda lain yang ada di bengkulu.

\section{Struktur Organisasi}

Struktur organisasi adalah kerangka hubungan antara satuan organisasi yang di dalamnya terdapat jabatan, tugas dan wewenang masing-masing mempunyai peran tertentu dalam kesatuan yang utuh. Jadi struktur organisasi akan menempatkan mengatur serta menyusun hubungan kerja sama baik antara orang maupun fungsi-fungsi dalam organisas. Secara umum uraian bentuk organisasi di atas yaitu Owner atau pemilik membawahi Branch Unit Head. Branch unit head bertanggung jawab atas Marketing Manajer Dan Branch Manager. Adapun uraian tugas dari masing-masing jabatan diatas yaitu :

Deskripsi Jabatan

Owner adalah pemilik perusahaan yang mempunyai tugas sebagai pemilik serta mengambil keputusan dan kebijakan dalam perusahaan. Owner mempunyai fungsi : Penetapan kebijakan operasional Perusahaan, Pengkoordinasian dan pengendalian Perusahaan. Rincian Tugas Owner : Menetapkan kebijakan operasional perusahaan PT. NSS, 
Mengkoordinasikan dan mengendalikan jalannya perusahaan, Menyelenggarakan rapat kerja dan memimpinnya. Branch Unit Head memiliki tugas selayaknya General manager mempunyai tugas pokok dalam rangka menjalankan operasional perusahaan sebagaimana di maksud, Branch Unit Head mempunyai fungsi:

Pengkoordinasian dan pengendalian jalannya kegiatan perusahaan PT. NSS. Melakukan pengontrolan terhadap penjualan. Melakukan pengontrolan terhadap bagian keuangan. Melakukan pengontrolan terhadap bagian administrasi pajak.

Melakukan pengontrolan terhadap bengkel. Dan melakukan pengontrolan terhadap para Supervisor dan Sales. Marketing Manager pada PT. NSS memiliki tugas mengendalikan dan mengontrol semua aktifitas penjualan oleh sales-sales PT. NSS, sekaligus memberikan laporan tentang administrasi penjualan kepada Branch Manager

Bertanggung jawab terhadap Branch Unit Head
Menetapkan tujuan dan sasaran jalannya operasional perusahaan dan strategi penjualan kepada konsumen Membuat analisa terhadap pangsa pasar dan menentukan strategi penjualan terhadap konsumen atau pelanggan. Menganalisis laporan yang dibuat oleh bawahannya, bertanggung-jawab terhadap perolehan hasil penjualan dan penggunaan dana promosi membina bagian pemasaran dan membimbing seluruh karyawan dibagian pemasaran.

Branch Manager memiliki tugas mengelolah bagian penjualan, penagihan dan pituang dan Menerima dan menganalisa laporan dari PIC PIUTANG, PIC.ADH dan PIC AHASS. Branch Manager juga memiliki tugas administrasi STNK dan Faktur dan personalia Administrasi STNK dan Faktur mempunyai tugas dan fungsi sebagai berikut : Menerima pengajuan pembuatan STNK motor baru dari para salesman, Membuat daftar pengajuan STNK motor baru per-hari, Mengajukan Faktur pembuatan STNK motor baru, Administrasi Personalia mempunya tugas dan fungsi di perusahaan sebagai berikut : Melakukan pendataan karyawan yang ada diperusahaan, 
Mengurusi hal yang berkaitan dengan karyawan perusahaan, Membuat laporan daftar gaji karyawan, Mengadakan penerimaan karyawan baru yang akan dibutuhkan oleh perusahaan, Mengajukan pembayaran gaji karyawan setiap awal bulannya ke bagian keuangan serta melampirkan daftarny MCSPV HMC merupakan bagian yang mengatur strategi marketing penjualan motor adapun tugasnya yaitu :

Membuat order pembelian

Melapor ke kasir perihal jumlah pembelian yang akan dibayar

Mengatur proses penjualan setiap hari

Membuat faktur penjualan

Menyeleksi faktur-faktur tagihan yang jatuh tempo untuk ditagih oleh tukang tagih selanjutnya di setor ke kasir

Membuat laporan penjualan masa bulanan dan mingguan

Deskripsi Data Penelitian

Jaringan Prosedur yang membentuk sistem penjualan kredit

Adapun jaringan prosedur yang membentuk sistem penjualan kredit pada PT. Nusantara Surya Sakti Bengkulu antara lain sebagai berikut :Prosedur Order Penjualan, dalam prosedur order penjualan ini, fungsi central order menerima permintaan dari pelanggan dan menyetujui permintaan tersebut. Fungsi central order kemudian membuat daftar pesanan barang dan mengirimkannya kepada berbagai fungsi yang lain. Fungsi penjualan membuat Nota dan mengirimkanya ke berbagai fungsi yang lain untuk memungkinkan fungsi - fungsi yang lain mengetahui harga barang dari pembeli atau pelanggan.

Prosedur Pengiriman, dalam prosedur pengiriman ini, fungsi produksi membuat barang sesuai dengan pesanan dan menyiapkan barang kemudian fungsi pengiriman mengirimkan barang dan Nota kepada pelanggan sesuai dengan informasi yang tercantum pada surat pengantar yang diterima dari fungsi central order yang sudah di otorisasi oleh fungsi pengiriman.

Prosedur Penagihan, dalam prosedur penagihan ini, fungsi akuntansi menerima nota dari fungsi penjualan dan membuat surat penagihan secara periodik kemudian mengirimkannya kepada pelanggan dengan dilampiri kwitansi.

Prosedur Pencatatan Piutang, dalam prosedur pencatatan piutang ini, fungsi 
akuntansi mencatat surat penagihan ke dalam buku piutang sebagai rekapan dari piutang PT. Nusantara Surya Sakti Bengkulu kepada pelanggannya,

Prosedur Distribusi Penjualan, dalam prosedur distribusi penjualan ini, fungsi akuntansi mencatat hasil transaksi penjualan kredit ke dalam jurnal penjualan.

Dokumen yang digunakan dalam sistem penjualan kredit

Daftar Pesanan Barang adalah dokuman yang berisi order permintaan dari pelanggan yang dibuat oleh bagian central order dan ditandatangani oleh central order, bagian produksi dan bagian akuntansi.

Surat Pengantar adalah surat yang memberikan otorisasi kepada fungsi pengiriman untuk mengirimkan barang kepada pelanggan.

Surat Penagihan adalah surat yang berisikan rincian tagihan atas piutang dan digunakan untuk menagih piutang yang timbul akibat transaksi penjualan kredit kepada pelanggan.

Nota dokumen yang berisikan harga barang dan sebagai bukti bahwa barang telah diterima oleh pelanggan.
Kwitansi adalah tanda bukti pembayaran pelanggan atas transaksi penjualan kredit.

Catatan akuntansi yang digunakan dalam sistem akuntansi penjualan kredit Adapun catatan akuntansi yang digunakan dalam sistem akuntansi penjualan kredit pada PT. Nusantara Surya Sakti Bengkulu yaitu :a. Buku Piutang, catatan akuntansi ini merupakan buku pembantu piutang yang digunakan untuk mencatat berkurangnya piutang PT. NSS Bengkulu b. Jurnal Penjualan ini digunakan untuk mencatat penjualan baik secara tunai maupun kredit berdasarkan informasi yang diterima.

Unsur - unsur pengendalian intern dalam sistem penjualan kredit

PT. Nusantara Surya Sakti Bengkulu melakukan pengendalian intern terhadap sistem penjualan kredit sebagai berikut :

Organisasi (Bagian Penjualan terpisah dari bagian penagih, Bagian Penjualan di pegang oleh Bagian Penjualan dan Bagian, Penagihan di pegang oleh Bagian Akuntansi, Bagian akuntansi terpisah dari bagian penjualan) 
Sistem Otorisasi dan Prosedur Pencatatan (Order dari pelanggan di otorisasi oleh bagian Central Order dengan menggunakan Daftar Pesanan Barang, Pengiriman produk di otorisasi oleh fungsi pengiriman dengan menanda tangani Surat Pengantar dan nota, Pencatatan kedalam Buku Piutang dan kedalam jurnal penjualan di otorisasi oleh fungsi akuntansi dengan cara menanda tangani Surat Penagihan dan Nota, Praktik yang Sehat, Penggunaan dokumen dengan bernomor urut tercetak, Secara periodik Bagian akuntansi mengirimkan pernyataan kepada pelanggan, Karyawan yang professional. Kualitas karyawan ditentukan oleh tiga aspek, antara lain : Pendidikan karyawan, Pengalaman karyawan, kinerja karyawan dan untuk karyawan bagian sales diperhitungkan penjualan karyawan tersebut)

Dokumen yang digunakan dalam sistem akuntansi penjualan kredit

Berdasarkan sistem PABU menurut Mulyadi (2008) dalam bukunya Sistem Akuntansi, dokumen yang digunakan dalam sistem akuntansi penjualan kredit adalah:

Surat order Pengiriman dan tembusanya
Faktur dan tembusanya

Rekapitulasi Harga Pokok Penjualan

Bukti Memorial

Catatan akuntansi yang digunakan dalam sistem akuntansi penjualan kredit Berdasarkan sistem PABU menurut Mulyadi (2008: 218), catatan akuntansi yang digunakan adalah:

Jurnal Penjualan untuk mencatat transaksi penjualan baik penjualan tunai maupun kredit.

Kartu Piutang, merupakan buku pembantu yang berisi mutasi piutang perusahaan kepada tiap debiturnya.

Kartu Persediaan, merupakan buku pembantu yang berisi rincian mutasi setiap jenis persediaan.

Kartu Gudang diselenggarakan oleh fungsi gudang untuk mencatat mutasi dan persediaan fisik barang yang ada di gudang.

Jurnal Umum digunakan untuk mencatat harga pokok produk yang dijual selama periode tertentu.

Unsur Unsur pengendalian intern terhadap sistem penjualan kredit

Berdasarkan PABU Menurut Mulyadi (2008: 221) unsur sistem pengendalian intern dalam penjualan kredit terdiri dari: 
1.Organisasi yang meliputi : Fungsi penjualan harus terpisah dari fungsi kredit, Fungsi akuntansi harus terpisah dari fungsi penjualan dan fungsi kredit, Fungsi akuntansi harus terpisah dari fungsi kas dan transaksi penjualan kreidt harus dilaksanakan oleh fungsi penjualan, fungsi kredit, fungsi pengiriman, fungsi penagihan dan fungsi akuntansi.

2.Sistem otorisasi dan prosedur pencatatan yang meliputi : Penerimaan order dari pembeli diotorisasi oleh fungsi penjualan, persetujuan pemberian kredit diberikan oleh fungsi kredit, pengiriman barang kepada pelanggan diotorisasi oleh fungsi pengiriman. Penetapan harga jual, syarat penjualan, syarat pengangkutan barang dan potongan penjualan berada di tangan Direktur Pemasaran dengan penerbitan surat keputusan mengenai hal tersebut. Terjadinya piutang diotorisasi oleh fungsi penagihan dengan membubuhkan tanda tangan pada faktur penjualan. Pencatatan ke dalam Kartu Piutang dan ke dalam jurnal penjualan, jurnal penerimaan kas dan jurnal umum diotorisasi oleh fungsi akuntansi dengan cara memberikan tanda tangan pada dokumen sumber (faktur penjualan, bukti kas masuk dan memo kreditPencatatan terjadinya piutang didasarkan pada faktur penjualan yang didukung dengan surat order pengiriman dan surat muat.

3.Praktik yang sehat yang terdiri dari Surat order pengiriman bernomor urut tercetak dan pemakaianya di pertanggung jawabkan oleh fungsi penjualan, Faktur penjualan bernomor urut tercatak dan pemakaianya di pertanggung jawabkan oleh fungsi penagihan, Secara periodik fungsui akuntansi mengirim pernyataan piutang kepada setiap debitur dan Secara periodik diadakan rekonsiliasi kartu piutang dengan rekening kontrol piutang dalam buku besar.

4.Karyawan yang professional. Kualitas karyawan ditentukan oleh tiga aspek, antara lain : Pendidikan, Pengalaman dan Ahlak

\section{Kesimpulan}

Berdasarkan dari hasil penelitian dan pembahasan, maka dapat disimpulkan sebagai berikut :

1. Jaringan prosedur yang membentuk sistem penjualan kredit pada PT. Nusantara Surya Sakti Bengkulu yaitu 
prosedur order penjualan, prosedur pengiriman, prosedur penagihan, prosedur pencatatan piutang, dan prosedur distribusi penjualan.

3. Dalam prosedur yang membentuk sistem penjualan kredit pada PT. Nusantara Surya Sakti Bengkulu sudah berjalan dengan baik.

Dokumen yang digunakan dalam prosedur penjualan kredit pada PT. Nusantara Surya Sakti Bengkulu meliputi Daftar Pesanan Barang, Surat Pengantar, Surat Penagihan, Nota, dan Kwitansi. Dalam penggunaan dokumen sistem penjualan kredit pada PT. Nusantara Surya Sakti Bengkulu sudah cukup baik, karena setiap kegiatan dalam penjualan kredit sudah menggunakan dokumen.

2. Catatan akuntansi yang digunakan dalam penjualan kredit pada PT. Nusantara Surya Sakti Bengkulu meliputi Buku Piutang, Jurnal Penjualan. Dalam catatan akuntansi masih sangat sederhana.

3. Bagian atau fungsi yang terkait dalam penjualan kredit pada PT. Nusantara Surya Sakti Bengkulu meliputi Bagian Central Order, Bagian Penjualan, Bagian Produksi,
Bagian Pengiriman, Bagian Akuntansi. Dalam bagian yang terkait pada PT. Nusantara Surya Sakti Bengkulu perlu adanya bagian gudang agar penjualan bisa berjalan dengan lancar.

Unsur Pengendalian intern yang terdapat pada PT. Nusantara Surya Sakti Bengkulu yaitu Organisasi, Sistem Otorisasi dan Prosedur Pencatatan, serta Praktik yang Sehat.

\section{Saran}

Dalam sistem akuntansi penjualan kredit pada PT. Nusantara Surya Sakti Bengkulu sudah menerapkan suatu sistem dan pengendalian intern yang cukup baik, sehingga perusahaan dapat menciptakan suatu target yang telah ditetapkan. Untuk menghindari penyelewengan yang mungkin terjadi. PT. Nusantara Surya Sakti Bengkulu hendaknya mengadakan pemisahan fungsi antara fungsi akuntansi dan fungsi penagihan. Dan sebaiknya PT. Nusantara Surya Sakti Bengkulu juga menambah pencatatan harga pokok penjualan agar harga pokok produk yang dijual dapat diketahui jelas oleh fungsi akuntansi. 


\section{DAFTAR PUSTAKA}

Agoes, Sukrisno. (2004). Auditing Pemeriksaan Akuntan. Jakarta: Fakultas Ekonomi Universitas Indonesia.

Arikunto, Suharsimi, (2010). Prosedur Penelitian Suatu Pendekatan Praktik. Jakarta : Rineka Cipta.

Baridwan, Z. (2008). Sistem Akuntansi : Penyusunan Prosedur dan Metode. Edisi Kelima. Yogyakarta. BPFE

Burhan, Bungin. (2003). Analisis Data Penelitian Kualitatif; Pemahaman Filosofis dan Metologis ke Arah Penguasaan Model Aplikasi. Jakarta: Raja Grafindo Persada.

Iriyadi. (2014). Prosedur Sistem pengendalian Intern Pengeluaran Barang. Edisi Pertama. Jakarta: Mitra Wacana Media

Ikatan Akuntan Indonesia. (2011). Standar Akuntansi Keuangan. Jakarta: Salemba Empat.

Krismiaji, 2005. Sistem Informasi Akuntansi, Edisi Kedua; Yogyakarta : Akademi Manajemen. Perusahaan YKPN 
ISSN No 2086-7956 E-ISSN No 2615-5494

Jurnal AGRIBIS Vol 14. No. 1 Januari 2021 Hal 1711-1725 
